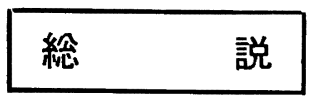

\title{
トリプトファン代謝異常による実験的糖尿病

\author{
Studies of Experimental Diabetes Caused by Xanthurenic Acid, \\ an Abnormal Metabolite of Tryptophan
}

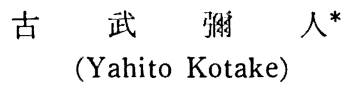

Since 1950 we have conducted a series of experiments on the diabetic symptoms in albino rats caused by the administration of xanthurenic acid (XA), an abnormal metabolite of tryptophan. Our studies have given conclusive evidence that $\mathrm{XA}$ is related to the development of human diabetes, a disease generally attributes to an inadequate food intake. Evidence also suggests that there is a close relationship between animal and human diabetes.

Experiments have shown that $\mathrm{XA}$ is a substance produced in the body as a result of intake of excess of the sodium salts of fatty acid (representing fat) and tryptophan (representing animal protein).

Taking into consideration the chronic nature of human diabetes, we then studied the development of chronic diabetic symptoms in rat caused by accumulative effect of XA produced in the body when vitamin $B_{6}$ deficient diet or excessive fat and tryptophan diet was administered for a long period. Then the pancreatic tissue of these rats was examined histologically. A decrease of stainability, a decrease in granules, much vacuole formation, and collapse of the protoplasm were noticeable in the $\beta$-cells of the islets of Langerhans.

We then examined fairly large amount of XA in the urine of many diabetic patients by the partition paper chromatographic method. These is an undeniable etiological relationship between free XA and human diabetes since a fairly large amount of $\mathrm{XA}$ in a free form present in the urine was invariably present in the urines of diabetic patients.

Murakami, one of our co-worker, recently showed that XA formed a binding complex with insulin. We have observed $\mathrm{XA}$ bound with insulin in human serum. XA-insulin complex showed a new fruorescence spectrum. The hormonal activity of XA-insulin complex was markedly decreased.

From these results we may suggest that experimental diabetes in the presence of XA may be induced by the following mechanism:

Tryptophan $\stackrel{\text { Vitamin } \mathrm{B}_{6} \text { deficient or excess } \mathrm{fat}}{\rightarrow} \underset{\text { Binding with insulin }}{\longrightarrow} \mathrm{XA}$. $\mathrm{XA}$-insulin complex Reduced insulin activity $\mathrm{XA}$ in the body
Overload on $\beta$-cells

今日ヒトの糖尿病発症の etiology は明碓でなく，そ の原因は一つではなく複数のものであることは，まず間 違いないだろう。以前上り唱えられてきた原因の一つと して遺伝性といらことが考えられる。遗伝性の存在はま す間違いないことながら，栄荃学的に考え，食物の摂取 状態といらことが糖尿病発症と大きな関係を持っている ことす間䢖いなかろ5。その証拁の一つとして，㘪争中 * 名古屋大学医学部

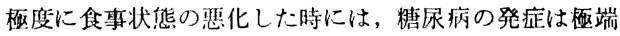
に減少し, 戦後状態の良くなった今日, 以前にも增し て糖尿病発症の增大したことがあげられる。このよ5な ことを考える時, 食物中のある栄羕素が異常代謝を扣こ し, 平常余り生成されない物澌が比粉的多量に生成され それが原因になって䌅尿病が発症することも一応考元ら れる。遗伝性にしても，ある䣼素の defect が仔在して いるため,このよ5な物質が体内に生成されやすい性質 
栄 扂

が遗伝しているのかも分らない。このようなことから栄

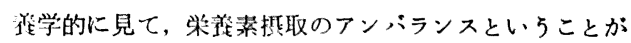

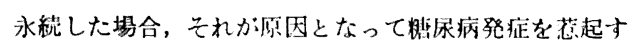
る可能性は十分考えられる。萃者らは15年以前上り，動 物を用いて多くの実耠を行ない,ビタミン $\mathrm{B}_{6}$ 欠乏食と か, 過剩の脂肪を繶けて摄取した場合, 体内にトリプト ファンの代謝異常をお。こし, そのため平常少量しか生成 されないキサントウレン酸 (XA) が多量に生成される。 このXA か榶尿病発症物質であるため，このよ5な食事 状照が長く続けば遂に膘尿病発症といら事熊になること を証明した。この研究は、ヒトの楛尿病の etiology を 解明する一つの approach を得たものと停じている。と 同時に栄㿥学的に, 栄营索の掜取に際して, 脂肪の過剩 摄取といらことには，䦌通が存するのではないかと考え られる。

我々は, 今から15年り以前に, 特に稲田鋭郎ととも に゙トリプトファンの代謝産物 XA が動物の糖尿病発症 物質であることをつきとめ, 確実なる代謝産物を用いて 始めて榶尿病動物を作ることに成功した。元来この XA なる物質は健常時には，雨めて少量しか体内に生成され ない物質であるが，ビタミン $\mathrm{B}_{6}$ 欠乏時，また過剩の脂 肪摄取時に多量に生成される。また近時著者たちの協同 研究者村上枝彦は，このXAがインシュリンと結合する ことを証明し，それに続いてこの XA-インシュリンー complex が, インシュリンとしてのホルモン活性の著 しい低下を確証して，ヒト糖尿病発症の etiology 研究 に一つの可能性を示すことができた。以下これら著者ら の研究の概略について述へ，ビタミン $\mathrm{B}_{6}$ 欠乏，また脂 肪過剩掑取ということと XA 楉尿の関倸について考えて みることとする。

\section{I. 生体内 XA 生成について}

$\mathrm{XA}$ 生体内生成に関して述べる前に, XA そのすのに ふいて少しく述べることとする。XAがトリプトフォン 代謝産物としてシロネズミ尿中より Musajo2)によって 発見されたのは1935年のことである。尿より得られた黄 色の酸とい5意味で Xanthurenic acid と命名された。 合成に成功して，4,8-dihydroxyquinoline-2-carboxylic acid であることが判明した。

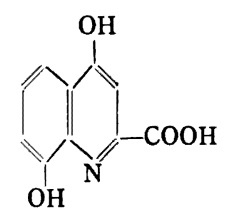

1942年より1943年にかけて Lepkowsky3) らによって V. $B_{6}$ 欠乏時に多量の XA が，体内にトリプトファンよ
と食䊅

り生成されることが判明した。この発見は,トリプトフ アン代謝に関しては偉大なる発見であった。その理由と

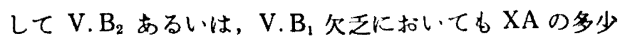
の增加排せつは拄められるが，V. $\mathrm{B}_{0}$ 欠泛時の增加排せ つは健労時の 20 倍にる邀し, これらの場合に比して比 較にならぬくらい大きいことがあげられる。そこで体内 にてXAの著明な生成增加があれば，必ず，直接，間接 V. $\mathrm{B}_{6}$ 欠乏と関係があると考えてよい。現在V. $\mathrm{B}_{6}$ 欠乏 の証明にしばしばこのXA 增加排せつが用いられること から考えてる理解できる。これらの事実はトリプトフっ ン代謝が正常に進むためにはV.B B $_{6}$ の分なる存在とい 5ことが必ず必要であることが了解できる。このXAの 生成といらことはトリプトファン代謝において栄養学上 なんら只献するところなくこの增加生成はむしろ有害 で,このXA 生成の少ないほどトリプトフォンは有意義 に体内で利用されていると考えてよい。その意味から言 っても，XA生成は，健常時には生体内に極めて少量 しか生成されず，V.B とい5よ5な栄蛍学上の一つの 欠宿が存する場合に, 体内に多産されると解される。こ れらの事実を証明される上において後程に述べるごとく トリプトファン代謝において重要な役制をつとめている キヌレニネース, キヌレニントランスフミネースなどの 醅素がピリドキサールリン酸を補醉点とする醉素である ことが Braunstein"によって証明されている。

XA は上述のごとく，健常時においてる生成されるが その量はきわめて少なく、トリプトファンはキヌレニン を経て主として完全分解されたり，また栄湌学上大切な 生理的意味を有すると考えられる NAD の生成, また ンスラニール酸の生成とい5ことが大きな意味をるって いると考えられる。従って上述のごとくXA の增加生成 といらことは,トリブトファンの栄養学的の大きな欠陥 といらことができる。そこで我々が害験研究している $\mathrm{XA}$ の增加生成の意義, いててこのXAによる実験的糖 尿病について以下述べることとする。

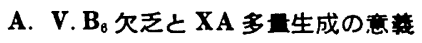

このことは Fig. 1 においてキヌレニンーフンスラニ ル酸，3-OHキヌレニンー3-OH フンスラニル酸なる代 謝経路に打いててこれら反応に関係ある酵素キヌレニネ 一スが，ピリドキサールリン酸を補酵素としている関係 上 V. $\mathrm{B}_{6}$ 欠乏時に本酵素活性が衰ろえ, これらの变化か 円滑に行なわれなくなり，その結果 XA が主として生成 されることより一応説明された。しかし, キヌレニンー キヌレン酸, 3-OH キヌレンン $\rightarrow \mathrm{XA}$ なる両反応を触媒 する醭キヌレニントランスアミネースるまた，ピリ ドキサールリン酸を補醳尜としている事実より, 以上の 説明では満足な解決が与えられなくなった。 
Fig 1.

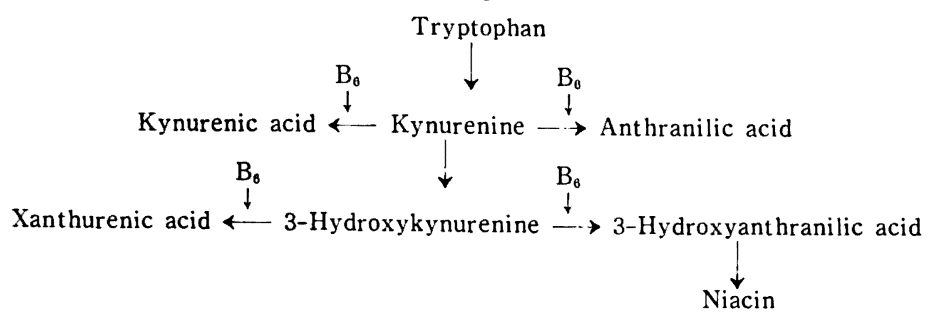

今回我々 ${ }^{3)}$ は、この意義の説明を両酵素の細胞内分布 により説明することができた。このことに関して説明す る。

Table 1. Distribution of Kynurenine-Transaminase and Kynureninase

\begin{tabular}{l|cc|c}
\hline & \multicolumn{2}{|c|}{ Kynureninase } & $\begin{array}{c}\text { Kynurenine- } \\
\text { transaminase }\end{array}$ \\
\cline { 2 - 3 } & Liver Kidney & Kidney \\
\hline $\begin{array}{l}\text { Mitochondria } \\
(700-9,000 \times \mathrm{g})\end{array}$ & 3.4 & 3.6 & 42.7 \\
$\begin{array}{l}\text { Microsome } \\
(9,000-105,000 \\
\times \text { g })\end{array}$ & 5.1 & 4.4 & 3.0 \\
\begin{tabular}{l} 
Supernatant \\
\hline
\end{tabular} & 91.5 & 92.0 & 54.3 \\
\hline
\end{tabular}

Table 1.に示すよ5にキキレンントランスアミネ ース活性の $40 \%$ ，細胞内に括いてミトコンドリフに存 在するのに反して, キヌレニネースの全活性は, 上清部 分のみに存している。

つぎに V. $\mathrm{B}_{6}$ 欠乏時の細胞内両分画の両酵素活性の変 動を検査した。(体重 $40 \mathrm{~g}$ 前後のシロネズミにV. $\mathrm{B}_{6}$ 欠 そ食を30日間投与）
全ホモジネートを用いて梌査すると Fig. 2 の如く, キヌレニネース活性は，刘顺動物の $25 \%$ まで低下したが キヌレニネーストランスアミネース活性は，50\%にまて 低下したに過ぎない。これらの結果は Mason らの)のそ れとよく一致している。つぎに稩胞内各分画について雨 醉素活性の変動については，上消缡のみに存するキスレ ニネースの全活性とキヌレニントランスフミネース全活 性の $60 \%$ を占める上清部の活性は，V. $\mathrm{B}$ 。 欠乏により殆 んどその活性が消失するのに反して，全活性の $40 \%$ を占 めるミトコンドリア中のキヌレニントランスアミネース 活性は、ごくわずか活性の低下をみるに過ぎない。

(Fig. 2 は比活性を\%で示している)

この実験によって，V. $\mathrm{B}_{6}$ 欠乏シロネズミに括いて肝 または腎中の上清部のみに存在しているキヌレニネース 活性は，ほとんど消失するのに反して，ミトコンドリフ に存する全活性の $40 \%$ を占めるキヌレニントランスフミ ネース活性は残存し, 体内の 3-OH キヌレニンの大部分 は，XAに移行することが判明した。以上両䣼索の細胞 内分布により, V. $\mathrm{B}_{6}$ 欠乏時に XA の多量生成される理 由を明確にすることができた。

B. 脂酸ソータ投与または高脂助食捸取による XA

Fig. 2.

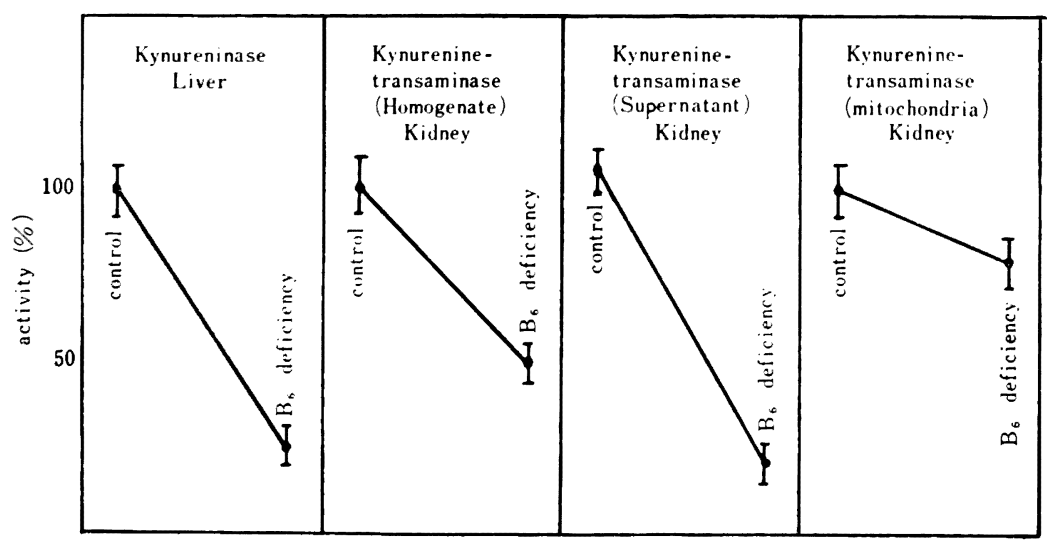

Activities of Kynurenine-transaminase and Kynureninase in Vitamin $B_{6}$ deficient rats. 


\section{の增加生成}

我々1はトリプトファン $(0.1 \mathrm{~g})$ とともに脂酸ソーダ 例えば酪酸ソーダ $(0.4 \mathrm{~g})$ をともにシロネズミに投与し て，その尿中より多量のXAを見出した。ここに新しく トリプトファンと脂肪の過剩抵取といらことがトリプト ファン代謝の县常を来すことを知った。Table 2.はトリ プトファンと各脂酸ソーダを体重 $120 \mathrm{~g}$ のシロネズミに 投与した時の XA 排せつの㥞子を示している。

Table 2.

The amount of XA excreted in 24 hours after administration of tryptophan and various fatty acids. Urine XA was determined by Glazer's method. To albino rats, weighing $120 \mathrm{gm}, 0.1 \mathrm{gm}$ of tryptophan and $0.4 \mathrm{gm}$ of the sodium salts of various fatty acids were simultaneously administered.

\begin{tabular}{l|c}
\hline \multicolumn{1}{c|}{ Substance administered } & $\begin{array}{c}\text { Amount } \\
\text { excreted }\end{array}$ \\
\hline Tryptophan alone & $1.61 \mathrm{mg}$ \\
Tryptophan plus sodium acetate & 5.37 \\
Tryptophan plus sodium propionate & 8.79 \\
Tryptophan plus sodium butyrate & 9.89 \\
Tryptophan plus sodium valerianate & 9.64 \\
Tryptophan plus sodium palmitate & 9.61 \\
Tryptophan plus sodium stearate & 8.57 \\
Tryptophan plus sodium oleate & 10.49 \\
\hline
\end{tabular}

つぎにこれら実験の意味うけに関する検討を行なっ た。この場合 Lepkowskyらの考え方を導入してV. $B_{\theta}$ 欠乏とXA多産とい5ことが, 脂酸ソーダ (脂肪) の過 剩投与といらことと何らかの関係があるのではないかと の考えをもった。そこで酪酸ソーダ投与群, 脂肪過剩投 与群 (35\%ハ⿱タ一食長期投与) の各群を作り, それらシ ロネズミ肝中のピリドキサールリン酸の定量を行なっ た。定量法は市原到の方法によった。またピリドキシン $5 \mathrm{mg} / 100 \mathrm{~g}$ body wt. を各群のシロネズミに注射後, 同じく肝ピリドキサールリン酸量を定量した。その結 果7をつぎに示す。

Fig. 3 に示与如く, 朋中ピリドキサールリン酸量は, 確実に V. $\mathrm{B}_{6}$ 久乏群, 酪酸ソーダ投与群, 高脂肪長期投 与群では，対照に比して減少を示している。かつピリド キシン $5 \mathrm{mg} / 100 \mathrm{~g}$ body wt. 投与した場合, V. $\mathrm{B}_{6}$ 欠乏 群のピリドキサールリン酸の增加量は, 対照の健常時と なんら異ならないが, 酪酸ソーダ投与群, 高脂肪長期投与 群の各々では, 明らかにピリドキサールリン酸の增加量
Fig. 3.

Pyridoxal phosphate concentration under various conditions

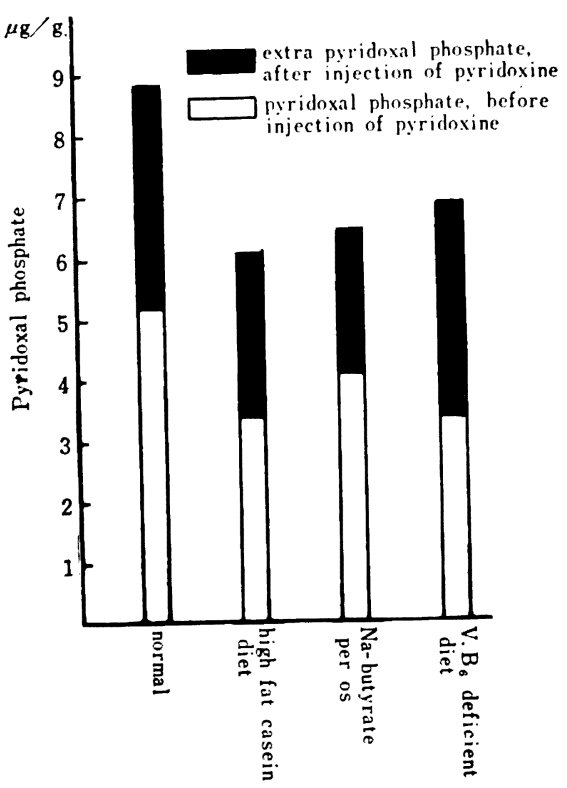

の少ないことが認められた。そこでンロネズミの体内に おいて，ピリドキシンが活性型のピリドキサールリン酸 になる酵素反応において，多量の脂肪投与により阻害を 亏け，一種の V. $\mathrm{B}_{6}$ 欠乏になり，その結果 XA の多産 をきたすと推定した。以上の研究に対してその後中原, 渡辺, 森野, 坂本 ${ }^{8)}$ は, さらに酵点化学レペルで追求し, 次の結果を得た (Fig. 4)。すなわちシロネズミ体内にお。

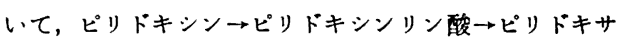
ールリン酸なる变化を認め, 脂酸ソーダ, 脂肪の過剩投

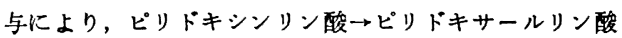
に関係する酵素活性が阻害を5け，ピリドキシンがピリ ドキサールリン酸になり難くなると結論した。

以上の研究よりトリプトファンの正常な代謝を行なら 上に打いてて V. $B_{6}$ 欠乏にならないこと，また過䣋の脂 肪摄取を避けることがぜひ必要であると考えられる。ト リプトファンより NAD, アンスラニル酸(キヌレニン経 由代謝)は生理的に大きな意味をもっている。これに反し てXAの多産は, XA 自体生理的になんら意味のない物質 と言ってょく，後述のように却って有害な産物と考えて よい。XA 自体がこのよらな物質であるのみならずこ のものの多産は他の有効なトリプトファン代謝産物, 例 えば組緶タンパク質生合成, NAD, アンスラニル酸七口 トニンなどの生成を妨げる結果になる。このような考兄 
Fig. 4.

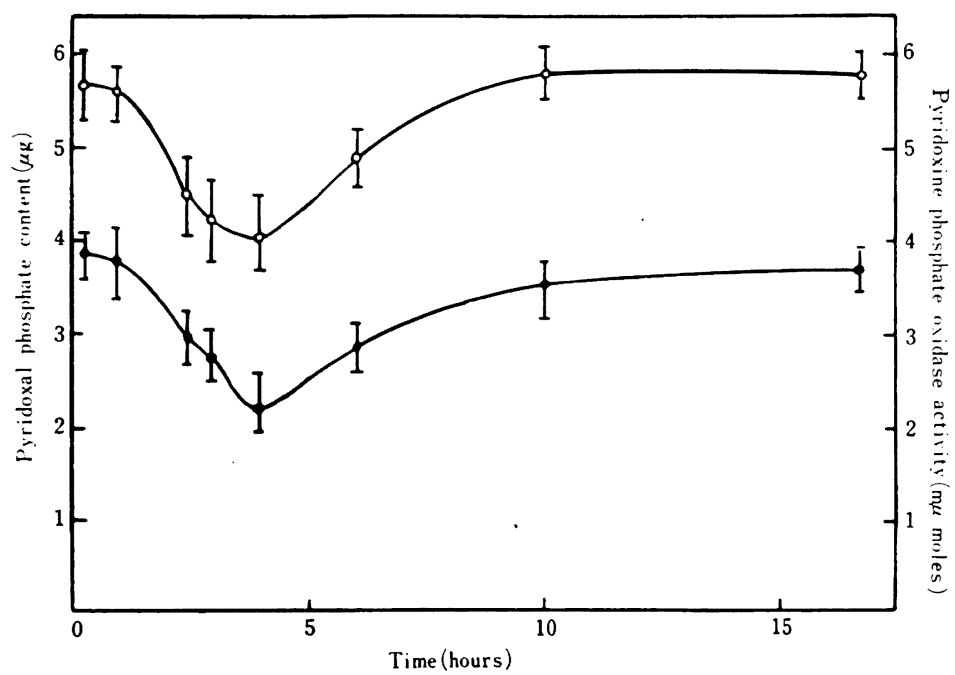

Variation of liver pyridoxal phosphate content and pyridoxine phosphate oxidase activity with time after oral administration of sodium butyrate $0.3 \mathrm{gm} / 120 \mathrm{gm}$. Open symbols represent pyridoxal phosphate content, and closed symbols pyridoxine phosphate oxidase activity. (坂本らが行なった結果)

から脂肪の過剩摂取を避けること，また十分なV. $\mathrm{B}_{6}$ を 摂ることはトリプトファン代謝を円滑にするためには， ぜ必要なことと考えられる。

\section{II. $\mathbf{X A}$ 亡実験糖尿病}

以上述べた研究結果が土台となって, 高脂肪・高トリ プトファン食(美食中に多く含まれている)，またV、B

Fig. 5.

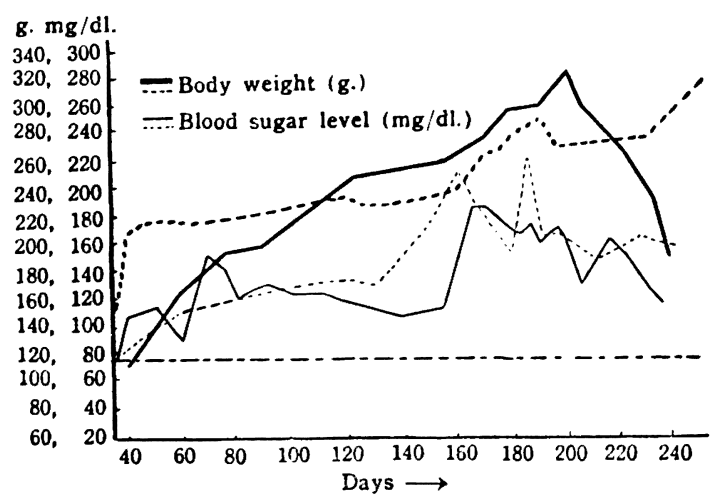

Body weight and blood sugar level after administering high fat and casein diet. Albino rats were fed for a long period on a diet containing much fat and casein.
そ食を長期にわたって摂取したシロネズミの体内に XA が增加し，そのXAによると考えられる実験的慢性糖尿 病発症を証明したのが, 次の Fig. 5, Fig. 6 に示す実 験である。以上のようなことはヒトに扎いても多くおこ りらる条件であるので, 或い:はトの糖尿病発症の原因 になる可能性を有しているのではないかと私は信じてい る。なお，酪酸ソーダとトリプトファンを同時投与した シロネズミ尿中より分離したXAを用いて 1 回 注射して行なった血糖曲線も併わせて Fig.7で 示しておく。

血栝の测定佉何れも King-Garner の方法に よって行なった。

$\mathrm{XA}$ 糖尿に関して最近我々の協同研究者の 1 人村上 ${ }^{10)}$ は，XA は試験管内で容易にインシュ リンと結合することを見出し，引きつついて血 清中に打いてもたやすく結合することを, 我々 は確めた。さらにこのXA-インシュリン結合物 のホルモンとしての作用を㭘した"11)。

インシュリン溶液を $\mathrm{pH} 8.0$ の Krebs-Ringer 液中にて XA 溶液と合一し， $37^{\circ} \mathrm{C}, 30$ 分 間保温してから Sephadex G-50 カラムを通 し、タンパク質部分を合一して流水透析を行な い, 余分の遊離の XA を除き，内容物を洲結跎 燥させる。得たものの炳光スペクトルをとると 
Fig. 6.

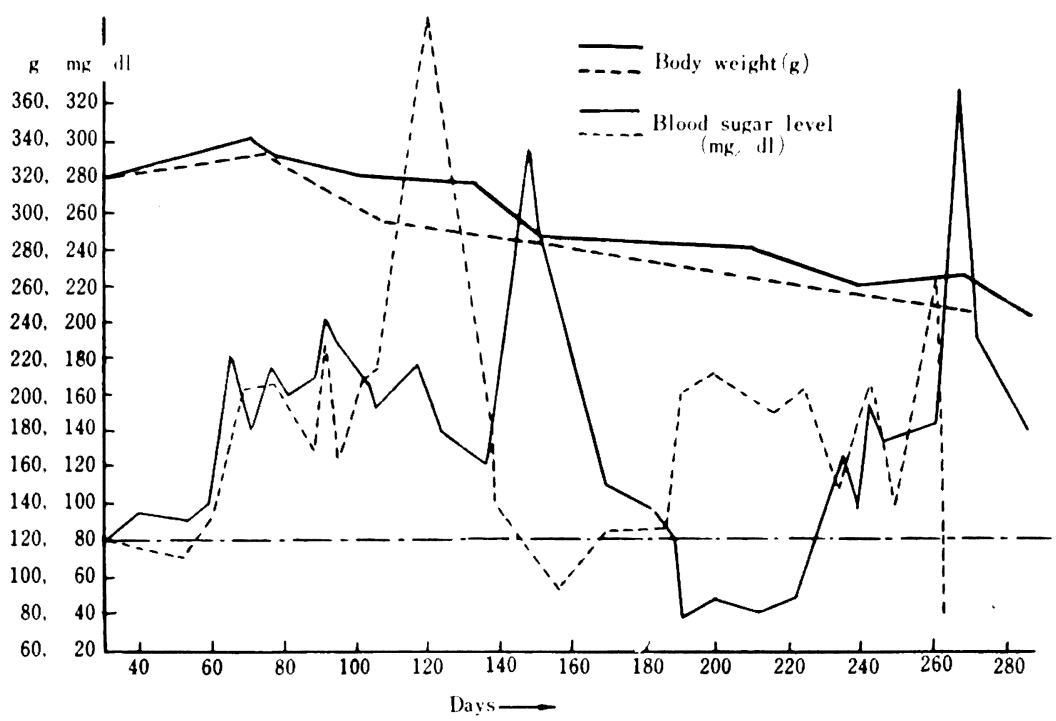

Body weight and blood sugar level after feeding on a vitamin $B_{6}$ deficient diet. Albino rats were fed for a long period on a diet deficient in vitamin $B_{6}$.

Fig. 7.

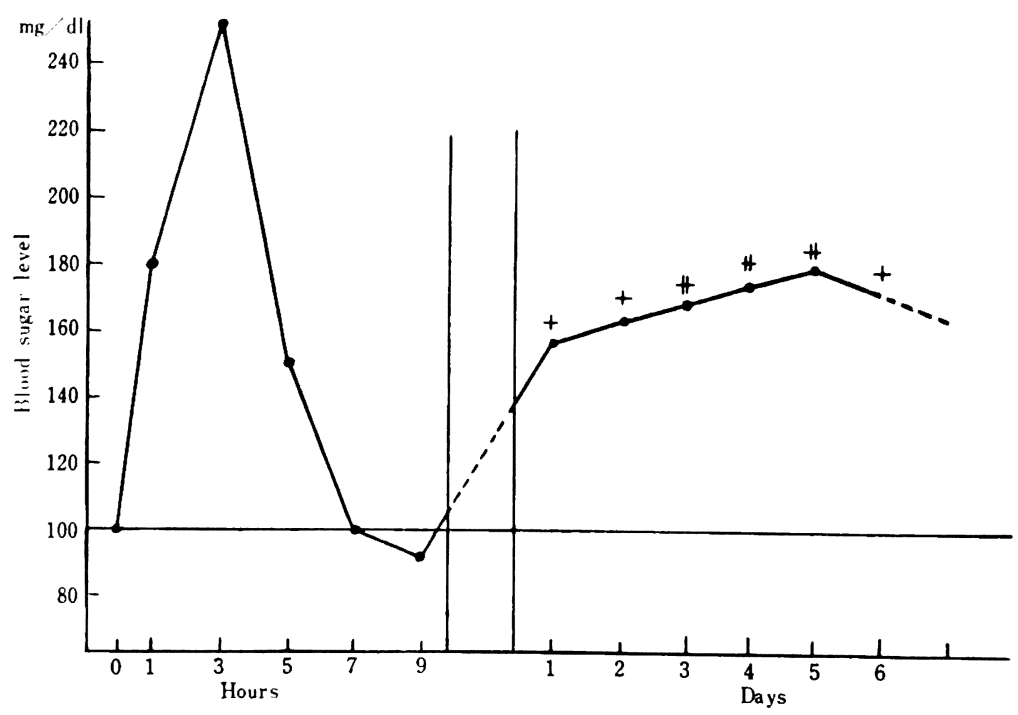

Blood sugar level after injection of xanthurenic acid. Male albino rats, weighing $150 \mathrm{gm}$ were employed. Xanthurenic acid $120 \mathrm{mg} / \mathrm{kg}$ was injected intraperitoneally.,+++ indicate the amount of glucose in the urine determined by Benedict's method. 
Fig. 8.

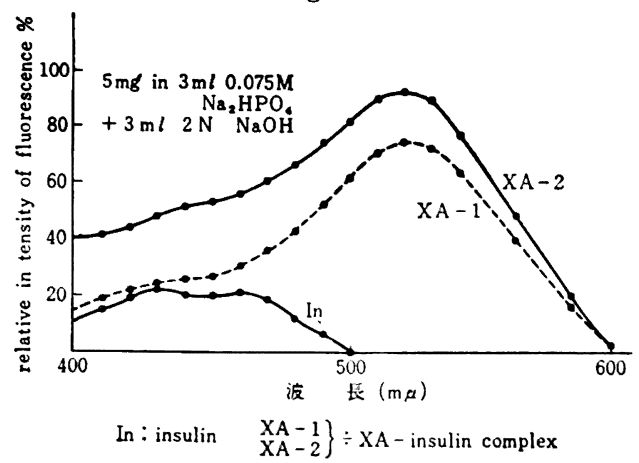

Fluorescence spectrum of $\mathrm{XA}$-insulin complex

Fig. 9.

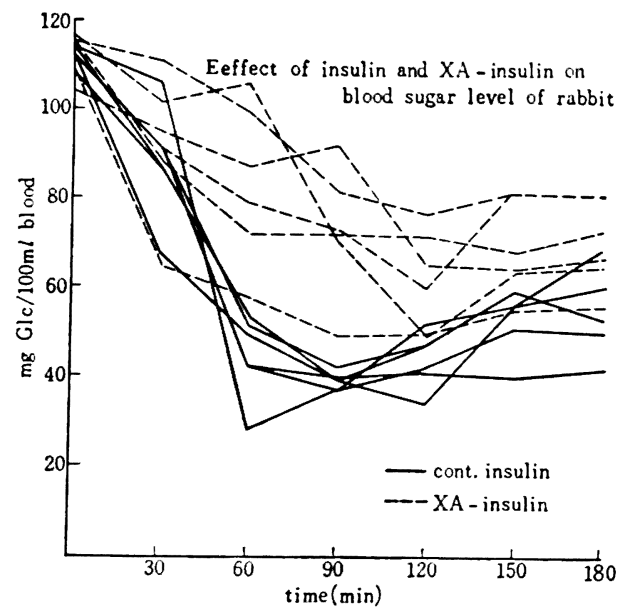

この結合物には新しい螢光特性が現われ，二物質の結 合を証明している。(Fig. 8)

この XA-インシュリン結合物についてホルモンとし ての作用を検した15)。

A）血糖降下作用，イヌ，ウサギについて実験を行な い両動物とも満足すべき結果を得た。ここではウサギを 用いての実験の結果を Fig. 9 に示す。血榶は Hagedorn-Jensen 法によって測定を行なった。

困に示すように XA-インシュリン結合物質のホルモ ンとしての活性は, インシュリンそのものの結晶のそれ の約 $50 \%$ の低い活性を示すに過ぎない。

B）つぎに Renold らの方法に従ってネズミの副睪丸 脂肪組線を用いて，グルコースのとりこみをしらべた。 その結果を Table 3 で示す。にの実駗は, 慈恵医科大
Table 3. Effect of XA on the uptake of glucose by epididymal fat pad of rat

\begin{tabular}{|c|c|}
\hline $\begin{array}{l}\text { Concentration in the } \\
\text { medium }\end{array}$ & Glucose uptake mg \\
\hline Basal Glucose $100 \mathrm{mg} / \mathrm{dl}$ & $0.25 \pm 0.07(6)$ \\
\hline $\begin{array}{r}1.0 / \mathrm{dl} \\
10.0 / \mathrm{dl} \\
100.0 / \mathrm{dl}\end{array}$ & $\begin{array}{l}0.29 \pm 0.11(5) \\
0.23 \pm 0.06(6) \\
0.31 \pm 0.07(7)\end{array}$ \\
\hline \multicolumn{2}{|c|}{$\begin{array}{l}\text { glucose } \mathrm{mg}=\text { glucose } \mathrm{mg} / 100 \mathrm{mg} \text { wet tissue } \\
\text { weight } / 4 \mathrm{hrs} \text { Numerical values in the paren- } \\
\text { theses indicate numbers of experiments. (阿部) } \\
\text { The effect of insulin and XA-insulin on } \\
\text { the uptake of glucose by epidymal fat } \\
\text { pad of rat }\end{array}$} \\
\hline medium & Glucose uptake mg \\
\hline $\begin{array}{l}\text { Basal } \\
\text { (Glucose } 100 \mathrm{mg} / \mathrm{dl} \text { ) }\end{array}$ & $\begin{array}{lll}0.25 & 0.07 & (6) \\
0.36 & 0.09 & (12)\end{array}$ \\
\hline+ Insulin $100 \mu \mathrm{u} / \mathrm{ml}$ & $\begin{array}{lll}0.60 & 0.14 & (6) \\
0.59 & 0.12 & (16)\end{array}$ \\
\hline$+\mathrm{XA}$ insulin $100 \mu \mathrm{u} / \mathrm{ml}$ & $\begin{array}{lll}0.38 & 0.12 & (7) \\
0.31 & 0.05 & (10)\end{array}$ \\
\hline
\end{tabular}

Glucose $\mathrm{mg}=$ Glucose $\mathrm{mg} / 100 \mathrm{mg}$ wet tissue weight $/ 4$ hrs Numerical values in the parentheses indicate numbers of experiments. (阿部)

学阿部内科教室との協同研究として行なわれた。)

$\mathrm{XA}$ 自体はなんら影響を示さないが，XAーインシュリ ンは, インシュリン自体のグルコースとりこみ增加作用 を殆んど示さない結果を得た。

以上の結果は, XA-インシュリン結合物は, ホルモン としての活性を著しく低下させる結果を得た。このよ5 に，XAがインュリンと結合することにより，その結 合物のホルモンとしての活性低下といらことを考えると

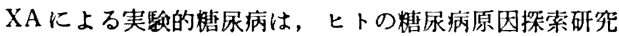
に一つの進展をもたらしたと考え，現在研究を続けてい る。我々は現在 XAによる実験的榶尿病発症の etiology をつぎの如く考えている。

脂肪, トリプトファンの過食一XA 多屏

$\mathrm{XA}$ とインシュリン結合 $\rightarrow \mathrm{XA}-$ インシュリン complex 生成

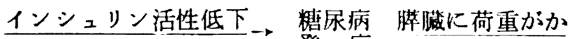

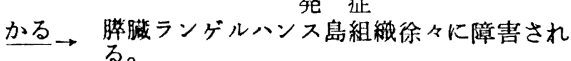




\section{栄養と食 糧}

\section{文献}

1) Kotake, Y. \& Inada, T.: J. Biochem., 40, 287 (1953)

2) Musajo, L.: Atti Acad. Linsei, 21, 368 (1935)

3) Lepkowsky, S., Roboz, E. \& Haagen-Smit, A.: J. Biol. Chem., 149, 195 (1943)

4) Braunstein, A. E.: Biokhimiya, 18, 393 (1953)

5) Kotake, Y., Ogasawara, N. \& Hagino, Y.: Proc. Jap. Acad., 38, 223 (1962)

6) Mason, M. \& Berg, C. P.: J. Biol. Chem., 195,
515 (1952)

7) 中井 愁: 和歌山医学, 8, 33 (1957)

8) Nakahara, I., Watanabe, Y., Morino, Y., \& Sakamoto, Y.: J. Biochem., 49, 343 (1961)

9) Kotake, Y., Inada, T., Matsumura, Y.: J. Biochem., 41, 255 (1954)

10) Murakami, E.: J. Biochem., 573, 63 (1968)

11) Kotake, Y., Sotokawa, Y., Murakami, E., Hisatake, A., Abe, M. \& Ikeda, Y.: J. Biochem., 578, 63 (1969) 